\title{
FLEXIBLE ALUMINIUM-AIR BATTERY FOR ENURESIS ALARM SYSTEM
}

\author{
Ugis Briedis, Aleksandrs Valisevskis, Zane Zelca \\ Riga Technical University, Latvia \\ ugis.briedis@rtu.lv, aleksandrs.valisevskis@rtu.lv, zane.zelca@rtu.lv
}

\begin{abstract}
This paper describes a study, which proposes an alternative and safe energy source, namely, a flexible aluminium-air battery that is suited for use in special garments and wearable products, particularly those worn by children. The need for such a battery has arisen in our recent study, in which we have developed a textile-circuitbased enuresis alarm system. The system is primarily intended for use by children while they sleep, hence the use of lithium ion or other traditional batteries poses serious safety risks. The proposed battery uses saline electrolyte and all of its elements are flexible, which makes it particularly suitable for use in such specialized arrangements, where the appearance of a physiological or other type of saline electrolyte (urine, sweat, blood) energizes and activates the system. This paper studies constructive particularities of such a battery, arrangement of its components, as well as electrical properties and possible applications in medical and smart childcare products, e.g., the enuresis alarm system, smart diapers etc. Methods of integration of the developed batteries in textile products are described, which are based on our previous experience and studies. The developed battery enables one to replace a split "sensor/processing unit" system with an energy source, which actively reacts to changes in its environment and generates electricity. Low costs of the proposed battery, as well as the availability of its main components, make it perfect for wide range of applications from human and animal care to consumer products.
\end{abstract}

Keywords: aluminium-air battery, flexible battery, smart textiles, embroidery.

\section{Introduction}

In one of our previous studies, we developed a textile enuresis alarm for children [1], which is intended to be worn by children during their sleep in order to treat enuresis. One of the main issues that has arisen during the study was related to the energy source. The system had to be autonomous and it was not feasible to use external power supply. Most commercially available chemical energy sources pose a certain degree of hazard due to their components - they either contain toxic materials or even pose explosion risk if not wired properly. One of the most promising alternatives was to use aluminium-air batteries due to the advantages described below. Besides that, since these batteries can be used with saline electrolytes, it is possible to use urine or other physiological liquids for their activation. As can be seen in the experimental results below, the activation of the battery is rather fast after the liquid is applied.

Aluminium-air batteries are becoming more and more popular lately due to various factors, the major two being the abundance of aluminium in the Earth crust, hence its low price, and its relatively high theoretical voltage and energy density $[2 ; 3]$.

Another major advantage of aluminium-air batteries is that they can be made using safe and nontoxic materials. A basic design consists of an aluminium anode and a cathode, which needs to draw oxygen for operation. This can be accomplished by using a porous material, which traps air, such as carbon. Besides that, it is possible to use saline water solution as an electrolyte, which makes the battery completely safe.

The technology of metal-air batteries is not new, another popular type of such batteries is $\mathrm{Zn}$-air batteries [5, 6]; lately a progress has been made to overcome obstacles to the commercialization of this technology (e.g., the oxidation of aluminium in Al-air batteries). Thus, in order to define the scope of this paper clearly, it must be emphasized that we do not propose a novel or improved technology. Rather we apply the existent technology to produce a novel design of an energy source, which does not contain dangerous or noxious materials, in a soft and flexible package, which has a "textile" feel to it and besides that can be activated with bodily fluids.

The aim of this paper is to test several configurations of flexible aluminium-air batteries, which are suited to be used in smart textile applications, as well as to present the results of these experiments in order to see, which configurations are most promising and should be subjected to further studies.

In the next section, different configurations of flexible textile Al-air batteries are described. Then the experimental results are presented, analysed and the conclusions are drawn. 


\section{Flexible textile Al-Air energy source design}

Before defining the possible elements of an Al-air battery, let us define the major requirements for such batteries in the context of smart textile domain, as well as wearable human and animal care products.

Besides non-toxicity and safety of the materials, it is necessary to ensure that the battery is flexible and its operation does not cease upon deformation, so that the comfort of the final wearable/textile product is maintained.

Another practical consideration is to make this battery "stackable", which means that in case of necessity separate battery cells can be stacked upon one another in order to increase the final voltage and/or current of the energy source. Thus, the battery must be made of materials, which ensure that the liquid is soaked through them in order to reach the underlying cells.

One of the ways of making a textile anode is to apply a coating made of aluminium nanoparticles, which can be deposited by the magnetron sputtering method [4].

There is a great variety of components, which can be used in Al-Air battery design. We constrained the choice of the options, which were either readily available or could be obtained with the equipment at our disposal. In this paper, the following options for the Al-Air batteries are considered.

The following materials were tested as aluminium anode in a flexible battery:

- plain consumer-grade aluminium foil;

- $0.28 \mathrm{~mm}$ diameter aluminium wire woven mesh (\#18 x \#16 Mesh);

- textile materials coated with aluminium by magnetron sputtering: (1) polyester with one sputtered $240 \mathrm{~nm}$ layer of $\mathrm{Al}$ coating, (2) cotton with one sputtered $240 \mathrm{~nm}$ layer of $\mathrm{Al}$ coating, (3) cotton with two sputtered $240 \mathrm{~nm}$ layers of Al coating, (4) conductive PES material with $\mathrm{Ni} / \mathrm{Cu} / \mathrm{Ag}$ original coating with one sputtered $240 \mathrm{~nm}$ layer of $\mathrm{Al}$ coating.

The cathode consists of a $0.03 \mathrm{~mm}$ diameter copper wire mesh (\#100 Mesh) coupled with carbon in various forms.

- bulk carbon 2-3 mm granules;

- $5 \mathrm{~mm}$ non-woven air filter impregnated with carbon;

- embroidered cathode pack, which encapsulates a layer of carbon 2-3 mm granules, a layer of \#100 copper mesh and another layer of carbon 2-3 mm granules in a cotton jacket. Details of the preparation of this textile cathode are given in the next chapter.

\section{Preparation of Al-Air battery components}

For the sake of comparability, the size of all the elements is fixed at $50 \times 50 \mathrm{~mm}$.

The preparation of embroidered cathode pack, which encapsulates a layer of carbon 1-2 mm granules, a layer of \#100 copper mesh and another layer of carbon 1-2 mm granules in a cotton jacket, is described below. The fabrication process can be seen in Figure 1.

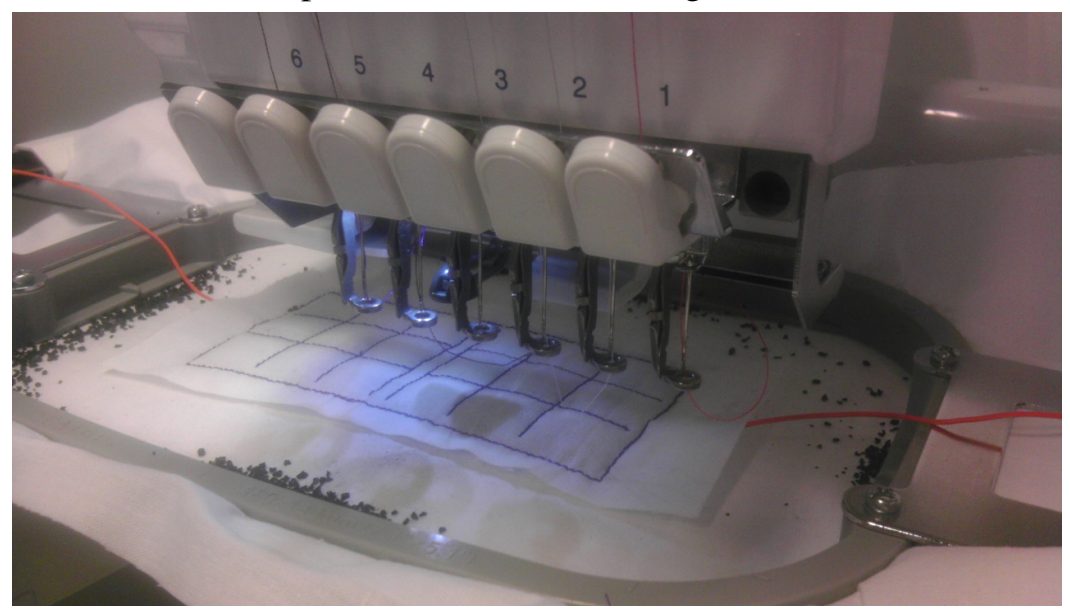

Fig. 1. Encapsulated carbon cathode preparation 
Embroidery machine Brother PR-600II was used for the preparation of the encapsulated cathode. Embroidered traces are programmed in embroidery CAD software Brother PE DESIGN.

The dimensions of each element are 50x50 mm. In order to optimize the process, two cathodes were produced in one run making the total dimensions of the embroidered part 50x115 mm.

The process is described below.

1. The fabric is doubled with a peel-off backing material (using an electric iron), so that the embroidered part is stabilized; afterwards it is inserted into a 180x130 mm embroidery frame.

2. The bedding for carbon is made with a two-pass $2 \mathrm{~mm}$ wide zig-zag stitch.

3. The first layer of carbon is poured into the bedding.

4. The copper mesh with two soldered wires is placed above the first layer of carbon.

5. The second layer of carbon is poured into the bedding.

6. The upper covering sheet is stitched along the outlines of the cathode to the base sheet, using a straight stitch (2.5 mm length).

7. The dividing line and reinforcing seams are produced using a straight stitch ( $2.5 \mathrm{~mm}$ length).

8. The cathode is removed from the frame.

9. The cathode is cut into two $50 \times 50 \mathrm{~mm}$ pieces.

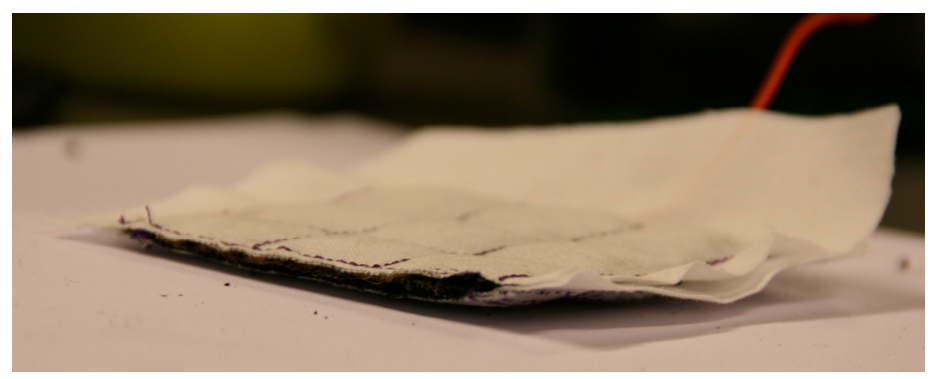

Fig. 2. Encapsulated carbon cathode

The resulting cathode pack can be seen in Figure 2, its total thickness is around $5 \mathrm{~mm}$.

Several anodes with Al coatings deposited by sputtering were tested as well. Magnetron sputtering was accomplished using lab equipment made by Angstrom Sciences and the process is summarized below.

The thin metal coatings are deposited by the magnetron sputtering method. The technical data of thin film deposition is given in Table 1.

Table 1

\section{Magnetron sputtering}

\begin{tabular}{|c|c|c|c|c|}
\hline Sample & $\begin{array}{c}\text { Target } \\
\text { Material }\end{array}$ & $\begin{array}{c}\text { Argon Gas } \\
\text { Flow, sccm }\end{array}$ & Rate, A· $\mathbf{s}^{-\mathbf{1}}$ & $\begin{array}{c}\text { Coating } \\
\text { Thickness, } \mathbf{n m}\end{array}$ \\
\hline Polyester fabric & $\mathrm{Al}$ & 10 & 2 & 240 \\
\hline Cotton fabric & $\mathrm{Al}$ & 10 & 2 & 240 \\
\hline Conductive fabric & $\mathrm{Al}$ & 10 & 2 & 240 \\
\hline
\end{tabular}

\section{Planning and carrying out experiments}

The electrolyte solution used in the experiments was prepared by mixing $300 \mathrm{~g}$ of $\mathrm{H}_{2} \mathrm{O}$ with $50 \mathrm{~g}$ of $\mathrm{NaCl}$. PicoScope $3204 \mathrm{~B}$ digital oscilloscope was used for voltage measurements. Voltage was measured for a duration of 5-10s or until it was stable. Due to the fact that this is a study in progress and only a couple of energy cell prototypes have been produced, each experiment was repeated once, but in our opinion it nevertheless gives a clear idea of relative performance of different element combinations given in this paper, which is the main objective at this phase of the study.

The first set of experiments was carried out with the most common material - aluminium foil. Four configurations were tested, which are described in Table 2. 


\section{Experiment results 1-4}

\begin{tabular}{|l|l|l|l|}
\hline No. & \multicolumn{1}{|c|}{ Configuration (bottom-up) } & $\begin{array}{l}\text { Voltage, } \\
\text { stabilisation time } \\
\text { (if available) }\end{array}$ & \multicolumn{1}{|c|}{ Notes } \\
\hline 1. & $\begin{array}{l}\text { aluminium foil, layer of cotton, } \\
\text { carbon granules, copper mesh, } \\
\text { carbon granules, layer of cotton. }\end{array}$ & $\begin{array}{l}\text { around } 720 \mathrm{mV} \\
\text { after around } 6 \\
\text { seconds }\end{array}$ & $\begin{array}{l}\text { Battery activation time was extremely fast }- \\
\text { around 0.1 s after the electrolyte has reached } \\
\text { the bottom of the battery, at this point the } \\
\text { voltage has jumped to 560 mV. Layers of } \\
\text { cotton are used as separators }\end{array}$ \\
\hline 2. & $\begin{array}{l}\text { aluminium foil, layer of cotton, } \\
\text { non-woven carbon filter, copper } \\
\text { mesh, non-woven carbon filter, } \\
\text { layer of cotton }\end{array}$ & $\begin{array}{l}\text { around } 620 \mathrm{mV} \\
\text { after around } 4 \\
\text { seconds }\end{array}$ & $\begin{array}{l}\text { Another configuration was tested with only } \\
\text { one non-woven layer, see Configuration } \\
\text { No. 3 }\end{array}$ \\
\hline 3. & $\begin{array}{l}\text { aluminium foil, layer of cotton, } \\
\text { non-woven carbon filter, copper } \\
\text { mesh, layer of cotton }\end{array}$ & around $540 \mathrm{mV}$ & $\begin{array}{l}\text { In this and some of the further experiments it } \\
\text { was not possible to determine the activation } \\
\text { time, because the materials were already wet } \\
\text { after the previous tests }\end{array}$ \\
\hline 4. & $\begin{array}{l}\text { aluminium foil, embroidered } \\
\text { cathode }\end{array}$ & $\begin{array}{l}\text { around } 720 \mathrm{mV} \\
\text { after } 1 \text { second } \\
\text { the to the compact design, upon activation } \\
\text { milliseconds. The cathode is encapsulated, so } \\
\text { no additional insulating layers are necessary. } \\
\text { This design has one of the highest voltage } \\
\text { values and is the most stable energy source } \\
\text { so far }\end{array}$ \\
\hline
\end{tabular}

In the next set of experiments, aluminium foil was replaced by aluminium mesh:

\section{Experiment results 5-8}

\begin{tabular}{|l|l|l|l|}
\hline No. & \multicolumn{1}{|c|}{ Configuration (bottom-up) } & $\begin{array}{c}\text { Voltage, } \\
\text { stabilisation time } \\
\text { (if available) }\end{array}$ & \multicolumn{1}{|c|}{ Notes } \\
\hline $\mathbf{5 .}$ & $\begin{array}{l}\text { aluminium mesh, layer of } \\
\text { cotton, carbon granules, copper } \\
\text { mesh, carbon granules, layer of } \\
\text { cotton }\end{array}$ & around $700 \mathrm{mV}$ & - \\
\hline $\mathbf{6 .}$ & $\begin{array}{l}\text { aluminium mesh, layer of } \\
\text { cotton, non-woven carbon filter, } \\
\text { copper mesh, non-woven carbon } \\
\text { filter, layer of cotton }\end{array}$ & around $530 \mathrm{mV}$ & $\begin{array}{l}\text { Due to filter thickness another configuration } \\
\text { was tested with only one non-woven layer, } \\
\text { see Configuration No. 7 }\end{array}$ \\
\hline $\mathbf{7 .}$ & $\begin{array}{l}\text { aluminium mesh, layer of } \\
\text { cotton, non-woven carbon filter, } \\
\text { copper mesh, layer of cotton }\end{array}$ & around $500 \mathrm{mV}$ & - \\
\hline $\mathbf{8 .}$ & $\begin{array}{l}\text { aluminium mesh, embroidered } \\
\text { cathode }\end{array}$ & $\begin{array}{l}\text { around } 800 \mathrm{mV} \\
\text { after } 1 \text { second }\end{array}$ & $\begin{array}{l}\text { The highest voltage and most stable } \\
\text { performance among the first two experiment } \\
\text { sets }\end{array}$ \\
\hline
\end{tabular}

Taking into account the performance of the embroidered cathode during the first experiments, which were either not worse or better than any other configuration, as well as its optimal design for smart textile applications, it was decided to carry out the remaining experiments using only the embroidered cathode. The coated textile materials are covered in the last set of the experiments.

The most promising configuration is No. 8, which was studied further. The measured short-circuit current is $50 \mathrm{~mA}$. Due to the linear nature of battery operation, the I-V curve can be constructed, which is shown in Figure 3. 
Experiment results 9-12

\begin{tabular}{|l|l|l|l|}
\hline No. & \multicolumn{1}{|c|}{ Configuration (bottom-up) } & $\begin{array}{c}\text { Voltage, } \\
\text { stabilisation time } \\
\text { (if available) }\end{array}$ & \multicolumn{1}{|c|}{ Notes } \\
\hline 9. & $\begin{array}{l}\text { sputtered PES, embroidered } \\
\text { cathode }\end{array}$ & around $420 \mathrm{mV}$ & - \\
\hline 10. & $\begin{array}{l}\text { double sputtered cotton, } \\
\text { embroidered cathode }\end{array}$ & around $260 \mathrm{mV}$ & $\begin{array}{l}\text { Visually the aluminium coating was heavily } \\
\text { oxidized after double sputtering, which } \\
\text { probably caused poor performance of this } \\
\text { material }\end{array}$ \\
\hline 11. & $\begin{array}{l}\text { sputtered cotton, embroidered } \\
\text { cathode }\end{array}$ & around $350 \mathrm{mV}$ & - \\
\hline 12. & $\begin{array}{l}\text { sputtered conductive fabric, } \\
\text { embroidered cathode }\end{array}$ & around $140 \mathrm{mV}$ & - \\
\hline
\end{tabular}

After four weeks and two moistening-drying cycles, another set of experiments was made in order to determine battery operation and to study the I-V characteristic more thoroughly. In this set of experiments, the open-circuit voltage $(630 \mathrm{mV})$, the short-circuit current $(35 \mathrm{~mA})$ were measured, as well as several intermediate values in order to construct the I-V curve. The results are presented in Figure 3, which also demonstrates the change in battery performance during this period. One cell size is $50 \times 50 \times 5 \mathrm{~mm}$, so these data enable one to estimate the volumetric power density as $46 \mathrm{~W} \cdot \mathrm{m}^{-3}$, which is sufficient for the intended application of these cells, but will certainly be the subject of improvement efforts in further studies.

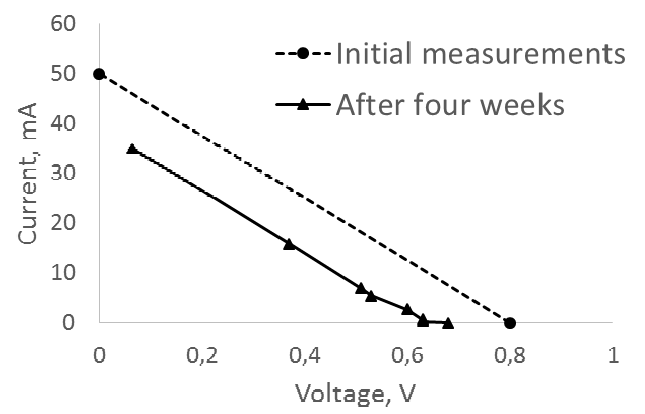

Fig. 3. Textile energy cell I-V curve, initial and after four weeks

\section{Results and discussion}

The first experiments show that Configuration No. 8 has yielded the most promising results regarding both the electrical and the operational characteristics. $800 \mathrm{mV}$ voltage level is barely at a level where it can be used to power common semiconductors - it might be necessary to stack several cells in order to operate common devices.

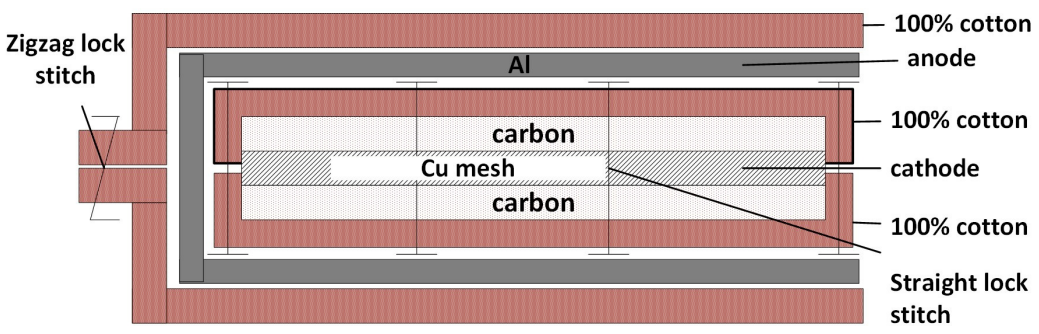

Fig. 4. Al-Air battery encapsulated in textile jacket

Besides that, further research and study is necessary to increase the output of this energy source, e.g., by increasing the surface area of the exposed aluminium cathode. For practical application, it is necessary to encapsulate this cell in an insulating material, such as cotton. This will ensure that the battery is not only flexible, but also has textile feel to it. The battery is also suitable to applications, 
which require short bursts of accumulated energy, typical to sensing scenarios. The ability to supply $3 \mathrm{~V}$ at $20 \mathrm{~mA}$ current for a couple of seconds can be a starting point for practical wireless sensing applications.

Figure 4 shows schematics of an encapsulating jacket for the developed Al-Air battery cell. Besides that, it shows how the surface area of the aluminium cathode can be doubled, almost without sacrificing the total thickness of the cell. The design described above ensures the long-term usability of the cell, because the battery can be easily "recharged" by changing the aluminium electrode after it is fully consumed.

The developed Al-Air cell can be applied in great variety of products. For example, enuresis alarm systems, where the battery can act not only as an energy source, but also for detecting moisture. Dry Al-air cells, which are activated only after a liquid electrolyte (such as urine) is applied, can be used as an emergency energy supply by special task forces, so that they have a readily available energy source for their electronic devices under extreme conditions.

As is mentioned in the introduction, the main objective of the study is to produce a flexible textile battery, which can be integrated into textile products, by taking advantage of one of the more suitable battery technologies, namely, Al-air batteries. Thus, it must be emphasized that the objective is not to improve the technology itself, but to apply it in a new setting, in order to open new possibilities. The initial results of this study are considered positive and promising - the energy cells are liquidpermeable, so can be stacked together in order to reach practical electrical characteristics.

\section{Conclusions}

1. This paper shows that a flexible textile Al-air battery cells can be produced, which yield energy output that can be sufficient for practical applications.

2. Textile Al-air cells are easily stacked together, because the electrolyte can flow through them.

3. Energy output of anodes coated with aluminium by magnetron sputtering method is low due to low aluminium content and heavy oxidation. Further research is needed in order to make this approach practically viable.

4. Further studies should focus on the usability characteristics of the developed energy cells in order to estimate the duration of operation, energy density and other parameters.

\section{Acknowledgment}

This work has been supported by the European Regional Development Fund within the project no. 1.1.1.1/16/A/020 "Synthesis of textile surface coating modified in nano-level and energetically independent measurement system integration in smart clothing with functions of medical monitoring".

\section{References}

1. Briedis U., Valisevskis A., Grecka M. Development of a Smart Garment Prototype with Enuresis Alarm Using an Embroidery-Machine-Based Technique for the Integration of Electronic Components. Procedia Computer Science, Volume 104, 2017, Pages 369-374.

2. Li, Q., Bjerrum, N.J. Aluminum as anode for energy storage and conversion: a review. Journal of Power Sources 110 (2), pp. 1-10, 2002. ISSN: 03787753.

3. Yang, S., Knickle, H. Design and analysis of aluminum/air battery system for electric vehicles. Journal of Power Sources 112 (1), pp. 162-173, 2002. ISSN: 03787753.

4. Vihodceva S. Extension of the Range of Textile Modified at Nano-Level. PhD Thesis. Riga: [RTU], 2014. 207 p.

5. Schroder D. Analysis of Reaction and Transport Processes in Zinc Air Batteries. ISBN-13: 9783658122904. Springer Vieweg. 2016.

6. Gu P., Zheng M., Zhao Q., Xiao X., Xue H., Pang H. Rechargeable zinc-air batteries: a promising way to green energy. Journal of Materials Chemistry A. DOI 10.1039/C7TA01693J. 2017. 